\title{
HEAT TRANSFER AT EVAPORATIVE CONCENTRATIAL SOLUTIONS IN VERTICAL DESCENDING ANNULAR FLOWS
}

\author{
V. Petrenko, M. Pryadko, O. Ryabchuk \\ National University of Food Technologies \\ O. Globa \\ PJSC "Vinnitsyaoblenergo"
}

\begin{tabular}{l} 
Key words: \\
Film \\
Liquid flow rate \\
Heat transfer \\
Evaporation \\
Film evaporator \\
\hline
\end{tabular}

Article history:

Received 15.01.2018

Received in revised form 29.01.2018

Accepted 14.02.2018

Corresponding author:

V. Petrenko

E-mail:

npnuht@ukr.net

\section{ABSTRACT}

The results of modeling heat transfer in liquid films of solutions heated to the saturation temperatures, flowing down over vertical cylindrical surfaces are presented. The experiments deal with the films evaporating from the interphase surface and in the regime of surface nucleate boiling. The films are studied in a regime of free falling and in the presence of co-current steam core. The range of regime parameters covered in the experimentation is characteristic for the working parameters of film evaporators of sugar industry and concentration of fruit juices. Experimental stand allowed an independent phase injection which enabled creation of any possible wavy structure on the falling film surface as well as formation of films with a wide range of film thickness. As modelling solutions are used: water, sugar solutions concentration up to $72 \%$, apple juice concentration up to $70 \%$. The volumetric liquid flux changed from $0,0510^{-3}$ up to $0,610^{-3} \mathrm{~m}^{2} / \mathrm{s}$, speed pair - up to $40 \mathrm{~km} / \mathrm{s}$, underpressure - up to 0,85 bar, a thermal stream — up to $60 \mathrm{kVt} / \mathrm{m}^{2}$. The geometry of experimental channels covers a range of lengths from 1,8 up to $9 \mathrm{~m}$, diameters - from 20 up to $32 \mathrm{~mm}$.

The analysis of data obtained by the authors along with those available in the literature allowed to formulate principal factors affecting mechanism of heat transfer to liquid films in the both patterns of evaporation, formulate the conditions of transition to surface nucleate boiling which occur in pipes of different diameters. The criterion for the transition to surface boiling on a heat exchange surface with a certain size of microcracks in conditions of gravitational flow with a co-current steam flow is the value of the minimal allowable wall overheating at which vapor bubbles develop, calculated on the basis of the Laplace and Clapeyron-Clausius relationships. The peculiarities of the influence of the steam velocity on the useful temperature pressure between the pipe wall and the film of the concentrated solution are revealed, the relationships for the correction of the useful temperature pressure and the calculation of the heat flux to annular down-flowing liquid films of solutions are presented.

The results of calculations for the obtained ratios of the distribution of heat flux over the height of long boiling pipes and the comparison of the calculation results with the experimental data for water and apple syrups are presented.

DOI: $10.24263 / 2225-2924-2018-24-1-20$ 


\title{
ТЕПЛОВІДДАЧА ПРИ ВИПАРОВУВАЛЬНОМУ КОНЦЕНТРУВАННІ РОЗЧИНІВ У ВЕРТИКАЛЬНИХ НИЗХІДНИХ КІЛЬЦЕВИХ ПОТОКАХ
}

\author{
В.П. Петренко, М.О. Прядко, О.М. Рябчук \\ Національний університет харчових технологій \\ О.В. Глоба \\ ПАТ «Вінниияобленерго»
}

У статті наведено результати моделювання теплообміну в догрітих до температури насичення плівках розчинів, що рухаються по вертикальній поверхні труб як у режимі випаровування з міжфазної поверхні, так і поверхневого кипіння, як в умовах вільного стікання, так $і$ за наявності швидкісного парового ядра в діапазоні зміни режимних параметрів, характерних для роботи випарних установок иукрових заводів та ВУ з концентрування фруктових соків. Фізичне моделювання виконано на експериментальному стенді з незалежним формуванням в кип'ятильному каналі витрат фаз $i$ теплового потоку, а також на установках, що моделюють реальні умови концентрування розчинів у плівкових випарних апаратах. Як модельні рідини використані: вода, иукрові розчини, концентрачією до 72\%, яблучний сік, концентрацією до 70\%. Об 'ємна щиільність зрочення змінювалась від 0,05 $10^{-3}$ до 0,6 $10^{-3} \mathrm{M}^{2} /$, швидкість пари - до $40 \mathrm{M} / \mathrm{c}$, розрідження - до 0,85 бар, тепловий потік - до $60 \mathrm{\kappa Bm} / \mathrm{M}^{2}$. Геометрія експериментальних каналів охоплює діапазон довжин від 1,8 до 9 м, діаметрів - від 20 до 32 мм.

Аналіз отриманих даних, а також даних інших авторів дав змогу виявити вилив на тепловіддачу до плівок і режимних параметрів, $і$ геометричних характеристик труб, а також сформулювати умови переходу до поверхневого кипіння. Критерієм переходу до поверхневого кипіння на теплообмінній поверхні з певним розміром мікротріщин в умовах гравітаційного стікання із супутним рухом парового ядра прийнята величина мінімально допустимого перегріву стінки, за якого розвиваються парові бульбашки, розрахованого на основі співвідношень Лапласа та Клапейрона-Клаузіуса.

Виявлено особливості впливу швидкості пари на корисний температурний напір між стінкою труби та плівкою концентрованого розчину. Розраховано співвідношення для коригування корисного температурного напору, розрахунку теплового потоку до кільиевих низхідних парорідинних потоків розчинів, а також узагальнюючі співвідношення для інженерних розрахунків коефіцієнтів тепловіддачі в трубах вертикальних плівкових випарних апаратів.

Наведено результати розрахунків за отриманими співвідношеннями розподілу теплового потоку по висоті довгих кип'ятильних труб та зроблено порівняння результатів розрахунку з експериментальними даними для води та яблучних сиропів.

Ключові слова: плівка, щүільність зрошення, теплопередача, випарювання, плівковий випарний апарат. 
Постановка проблеми. Аналіз процесів тепловіддачі до насичених турбулентних і ламінарних плівок цукрових розчинів у режимі випаровування 3 міжфазної поверхні з розвинутої хвильовою структурою надано в $[1 ; 2]$. Названа форма руху плівки є домінуючою в довгих теплообмінних трубах [3], а отримані в [1;2] співвідношення для коефіцієнтів тепловіддачі для ламінарних і турбулентних плівок адекватно відображають процеси теплоперенесення в довгих трубах плівкових випарних апаратів у режимі випаровування 3 міжфазної поверхні.

У той же час в [4-7] встановлено, що режим тепловіддачі, який ідентифікується як випаровування з міжфазної поверхні, реалізується лише до певного граничного перегріву стінки відносно температури насичення, за межами якого характер інтенсивності тепловіддачі змінюється під дією пульсацій, як результат утворення та руху парових бульбашок.

У [6] інтенсифікуючий вплив бульбашкового кипіння на процес тепловіддачі при вільному стіканні плівки води по зовнішній частині циліндра за умови сталого по довжині каналу тепловиділення визначено співмножником

$$
\left[1+0,05\left(\frac{q_{w}-q_{\text {incip }}}{q_{\text {incip }}}\right)^{1,36}\right]
$$

до базового рівняння з інтенсивності тепловіддачі до плівки в режимі випаровування з міжфазної поверхні. За мінімальний тепловий потік, за якого починається вплив бульбашкового кипіння на теплообмін $q_{\text {incip }}$, прийнято тепловий потік, що відповідає початку генерації бульбашок в окремих центрах кипіння $\left(q_{\text {incip }}=14,2 \frac{\kappa \mathrm{BT}}{\mathrm{M}^{2}}\right)$. Але дані, отримані в кип'ятильних трубах, вказують, що на процес початку кипіння впливає і конвекція рідини, тому більш вдалим параметром, що відображає початок впливу кипіння на інтенсивність тепловіддачі в плівці, є комплекс $\frac{q}{r \bar{u} \rho}$, використаний у [4], де умову початку впливу кипіння на теплообмін ідентифіковано виразом:

$$
\frac{q}{r \bar{u} \rho} \geq 1,5 \cdot 10^{-4}\left(\frac{\bar{u} \delta}{a}\right)^{-0,24} \operatorname{Pr}^{-0,3},
$$

де $\bar{u}-$ середня швидкість плівки; $\delta$ - товщина плівки; $r-$ теплота фазового перетворення; $a$ - температуропровідність; $\rho$ - густина рідини; $\operatorname{Pr}$ - число Прандтля.

У той же час комплекс $\frac{q}{r \bar{u} \rho}$ не відтворює відповідність дії тиску та розрідження на критичний тепловий потік, за якого починається поверхневе кипіння. До того ж ні $q_{\text {incip }}$, ні $\frac{q}{r \bar{u} \rho}$ не враховують шорсткості поверхні теплообміну, яка відіграє ключову роль у необхідному граничному перегріві 
стінки, за якого починається процес утворення бульбашок, тому наведені параметри лише частково характеризують умови переходу до бульбашкового кипіння в трубах реальних випарних апаратів.

Крім того, оскільки переважна кількість експериментальних робіт, присвячених питанням теплообміну в догрітих до температури насичення плівках, виконано на установках, що моделюють випарний апарат, отримані дані містять інформацію про теплообмін при одночасному впливі ряду факторів, без виділення впливу окремих складових. Тому і рекомендовані співвідношення для розрахунку інтенсивності тепловіддачі до насичених плівок у випарних апаратах обмежені як діапазоном режимних параметрів, в якому моделювався процес, так і конкретизацією геометрії дослідної установки.

Мета дослідження: отримати співвідношення для розрахунку інтегральних характеристик процесу теплообміну при випаровувальному концентруванні розчинів у плівках вертикальних низхідних потоків як у режимі випаровування 3 міжфазної поверхні, так і поверхневого кипіння в режимах, наближених до умов роботи плівкових випарних апаратів цукрової промисловості.

Матеріали і методи. Фізичне моделювання процесів теплообміну в стікаючих догрітих до температури насичення плівках цукрових розчинів виконано на модельній установці з незалежним формуванням витрат фаз i теплового потоку. В трубу з нержавіючої сталі діаметром 20 мм та довжиною 1,8 м, розділену на стабілізаційну ділянку довжиною 1,5 м та ділянку вимірювань, переливанням через край подавався цукровий розчин, а в разі моделювання паро-рідинного потоку і суха насичена водяна пара. Нагрівання здійснювалось сухою насиченою парою, тиск якої на ділянці стабілізації та вимірювань формувався незалежно один від одного. Нагрівна камера й трубний простір обладнані незалежними одна від одної вакуум-конденсаторними системами, що дало змогу встановлювати розрідження до 0,85 бар і в довільному діапазоні змінювати температурний напір. Відбори проб здійснювались безпосередньо за ділянкою вимірювань.

Крім того, використані експериментальні дані, отримані на модельній установці, що відтворювала реальні умови концентрування цукрових розчинів у плівковому випарному апараті. Установка складалась із теплообмінної труби із нержавіючої сталі, довжиною 9 м внутрішнім діаметром 30 мм, секціонованої на 20 секцій довжиною 440 мм з відведенням 3 кожної секції утвореного конденсату в окремі адіабатні мірні стакани. Після кожної секції розміщувались відбірники проб рідини та статичного тиску. Нагрівання здійснювалось сухою насиченою парою; температура стінки труби та ядра потоку вимірювалась мідь-константановими термопарами. Детальний опис експериментальної установки можна знайти в [4].

Аналогічна установка 3 довжиною труби 3,9 м діаметром 32 мм використовувалась для моделювання процесу концентрування яблучного соку під розрідженням.

Результати та обговорення. Універсальним параметром початку бульбашкового кипіння в плівці, успішно використаного Чжунем та Себаном [5] для ідентифікації процесу утворення парових бульбашок в стікаючій по вертикальній поверхні плівці, $є$ величина мінімального перегріву шорсткої стінки, 
розрахованої на основі співвідношень Лапласа та Клапейрона-Клаузіуса, яка встановлює відповідність критичного перегріву стінки $\Delta t_{\min }$ певному радіусу заглиблень мікротріщин $R_{c}$ за певного тиску чи розрідження:

$$
\Delta t_{\min }=\frac{2 \sigma T_{\text {sat }}}{r \rho_{2} R_{c}}
$$

де $T_{s a t}$ - абсолютна температура насичення; $\sigma-$ поверхневий натяг; $\rho_{2}-$ густина пари.

У разі кипіння розчинів перегрів стінки більше на величину фізикохімічної температурної депресії $\Delta_{f c}$ :

$$
\Delta t_{\min }=\frac{2 \sigma T_{s a t}}{r \rho_{2} R_{c}}+\Delta_{f c}
$$

Відомо, що інтенсифікація тепловіддачі внаслідок поверхневого кипіння зумовлена тим, що в мікротріщинах відповідного розміру в міру зростання температурного напору поступово 3'являються все нові центри генерації парової фази, що однозначно ідентифікується виразами $(3 ; 4)$. Крім того, величина $\Delta t_{\min }(3,4)$ адекватно реагує і на зміну тиску або розрідження на початок утворення бульбашок. Тому параметром, що характеризує інтенсифікацію тепловіддачі за наявності кипіння є величина, пропорційна температурному напору при $\Delta t \geq \Delta t_{\text {min }}$, яка $\epsilon$ співмножником до основного базового рівняння 3 тепловіддачі до плівки в умовах випаровування з міжфазної поверхні і має вигляд:

$$
K_{\text {boil }}=1+c\left(\frac{\Delta t-\Delta t_{\min }}{\Delta t_{\text {min }}}\right)^{n},
$$

де $c$ та $n-$ коефіціснти, які визначаються $з$ дослідних даних.

Отримане в [2] базове співвідношення для розрахунку інтенсивності тепловіддачі в режимі випаровування з міжфазної поверхні до плівок води та цукрових розчинів складне для практичного використання, особливо за наявності супутнього парового потоку, тому надається його інженерна апроксимація, яка має вигляд:

$$
\begin{aligned}
\frac{\alpha}{\lambda}\left(\frac{v^{2}}{g}\right)^{1 / 3}= & 1,12 \operatorname{Re}^{-1 / 3}\left(0,85+0,01 \mathrm{Pe}^{0,2}+4,5 \cdot 10^{-4} \operatorname{Pe}^{0,86} \operatorname{Pr}^{-0,2}\right) \times \\
& \times \sqrt{1+\left[7,5 \cdot 10^{-6} \operatorname{Re}_{2}\left(\frac{\rho}{\rho_{2}}\right)^{0,2}\right]^{2}} K_{\text {boil }} K_{L},
\end{aligned}
$$

де $K_{\text {boil }}$ - поправка на поверхневе бульбашкове кипіння ; $K_{L}$ - поправка на довжину та діаметр теплообмінного каналу; $\operatorname{Re}=\frac{4 \Gamma_{v}}{v}, \operatorname{Re}_{2}=\frac{u_{2} d \rho_{2}}{\mu_{2}}-$ 
числа Рейнольдса рідини та пари відповідно; $\mathrm{Pe}=\frac{4 \Gamma_{v}}{a}-$ число Пекле; $\Gamma_{v}-$ об'ємна щільність зрошення; $u_{2}$ - швидкість пари; $\mu_{2}$ - динамічна в'язкість пари; $d-$ діаметр труби; $v, a, \lambda-$ кінематична в'язкість, температуропровідність і теплопровідність розчину, відповідно.

Порівняння розрахункових за співвідношенням (6) та експериментальних даних з тепловіддачі до плівок води та цукрових розчинів в трубі діаметром 20 мм в режимі випаровування з міжфазної поверхні при вільному стіканні наведено на рис. 1 , а в умовах наявності супутнього парового потоку - на рис. 2, 3, 4.

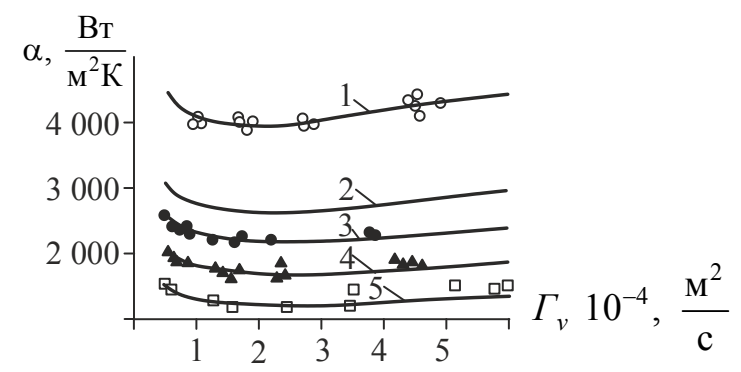

Рис. 1. Залежність $\alpha=\boldsymbol{f}\left(\boldsymbol{\Gamma}_{v}\right)$. Порівняння результатів розрахунку за (6) 3 експериментальними даними: 1 - вода, $t=100^{\circ} \mathrm{C} ; 2,3,4,5$ - цукрові розчини; $2-\mathrm{CP}=30 \% ; 3-40 ; 4-50 ; 5-60$

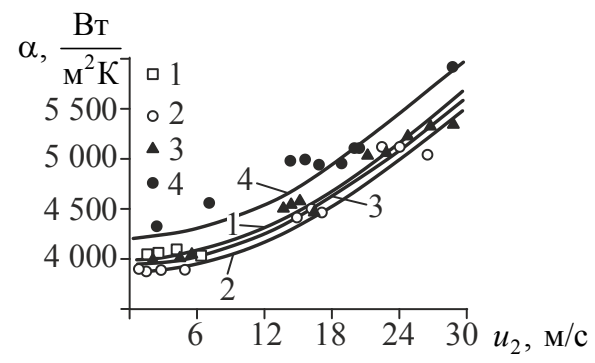

Рис. 2. Залежність $\alpha=f\left(u_{2}\right)$. Порівняння результатів розрахунку за (6) з експериментальними даними: вода, $t=100^{\circ} \mathrm{C} ; 1-\Gamma_{v}=0,110^{-3} \mathrm{~m}^{2} / \mathrm{c} ; 2-0,2$;

$$
3-0,3 ; 4-0,5
$$

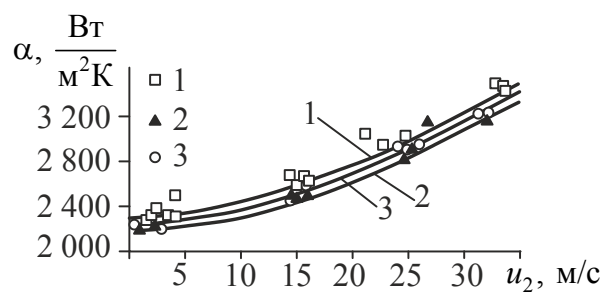

Рис. 3. Залежність $\alpha=f\left(u_{2}\right)$. Порівняння результатів розрахунку за (6)

з експериментальними даними: цукровий розчин, $\mathrm{CP}=40 \%, t=100^{\circ} \mathrm{C}$;

$$
1-\Gamma_{v}=0,110^{-3} \mathrm{~m}^{2} / \mathrm{c} ; 2-0,2 ; 3-0,35
$$




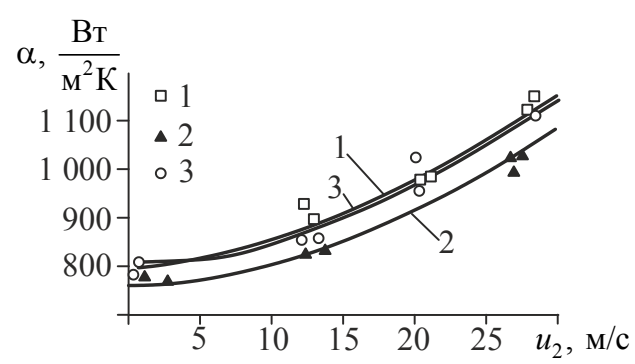

Рис. 4. Залежність $\alpha=f\left(u_{2}\right)$. Порівняння результатів розрахунку за (6) з експериментальними даними: цукровий розчин, $\mathrm{CP}=70 \%, t=100^{\circ} \mathrm{C}$, $1-\Gamma_{v}=0,110^{-3} \mathrm{M}^{2} / \mathrm{c} ; 2-0,3 ; 3-0,55$

Аналіз даних показує, що відповідність експериментальним даним про тепловіддачу при кипінні в плівках досягається за умови підстановки в (3) розмірів мікротріщин близько $R_{c}=0,5 \cdot 10^{-5} \mathrm{M}$, що відповідає шорсткості поверхні нових теплообмінних труб. Визначені коефіцієнти $c$ та $n$ у співвідношенні (5) дорівнюють, відповідно, $c=0,4$ та $n=1,2$.

Додатковим фактором, що порушує однозначність у способі обробки експериментальних даних про тепловіддачу до розчинів, $є$ нерівномірність розподілу концентрації за товщиною та вплив швидкості пари на температуру міжфазної поверхні. Так, унаслідок випаровування на міжфазній поверхні утворюється тонкий прошарок, в якому концентрація перевищує середнє значення, оскільки механізм вирівнювання концентрації лише за рахунок молекулярної дифузії надзвичайно повільний. Зважаючи на те, що поверхня плівки вкрита хвилями, які вносять елемент турбулізації навіть за малих чисел Рейнольдса, має місце невизначеність розподілу концентрацій у поперечному перерізі плівки.

Температура поверхні плівки розчину в режимі випаровування $t_{i}$ повинна дорівнювати температурі кипіння відповідно до концентрації на міжфазній поверхні $C_{i}$, тобто $t_{i}=t_{s a t}+\Delta_{f c}\left(C_{i}\right)$. Але величину $C_{i}$ визначити проблематично, тому, вважаючи, що поверхневі хвилі вирівнюють концентрацію, 3 певним наближенням можна прийняти, що $t_{i} \cong t_{s a t}+\Delta_{f c}(\bar{C})$, а коефіцієнт тепловіддачі при обробці експериментальних даних виразити як

$$
\alpha=\frac{q}{t_{w}-t_{i}}=\frac{q}{t_{w}-\left(t_{s a t}+\Delta_{f c}(\bar{C})\right)},
$$

де $\bar{C}-$ середня в перерізі плівки концентрація розчину; $t_{w}-$ температура стінки; $t_{s a t}$ - температура насичення.

Зважаючи на нелінійність профілю швидкості (в усталеному ламінарному режимі руху профіль швидкості параболічний), середня розрахункова температура плівки $t_{a v . m}$ в загальному випадку дорівнює: 


$$
t_{a v . m}=\int_{0}^{\delta} t(y) \frac{u(y)}{\bar{u}} d y \approx \frac{t_{w}+t_{i}}{2},
$$

де $t(y), u(y)$ - профілі температури та швидкості в перерізі плівки.

Водночас дані вимірювань засвідчили, що дослідна середньомасова температура плівки розчину $t_{a v . m}^{\exp }$, яка заміряна в адіабатній ємності безпосередньо на виході із дослідної ділянки (рис. 5) відповідає (8) лише за умови вільного стікання за відсутності міжфазної дотичної напруги.

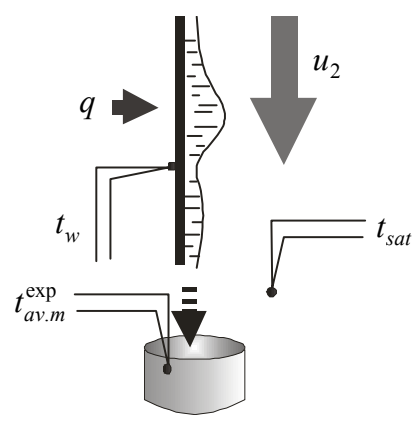

Рис. 5. Схема вимірювань температур у модельному каналі

При наявності швидкості пари над поверхнею плівки дослідна середньомасова температура розчину $t_{a v . m}^{\exp }$ менша $\left(t_{a v . m} \geq t_{a v, m}^{\exp }\right)$ від середньої розрахункової (8), а отримане відхилення тим більше, чим більша швидкість пари та щільність зрошення. 3 огляду на те, що температура $t_{a v . m}^{\exp }$ (на відміну від $t_{i}$ ) відчутно реагує на зміну режимних параметрів кільцевого двофазного потоку і є величиною, яка безпосередньо вимірюється в процесі проведення дослідів, то і коефіцієнти тепловіддачі для розчинів, визначені як

$$
\alpha_{m}=\frac{q}{t_{w}-t_{a v . m}^{\exp }},
$$

адекватно реагують на зміни витрат фаз. При цьому $\alpha \geq \alpha_{m}$.

Оскільки коефіцієнти тепловіддачі, що ідентифікуються співвідношенням (6), відповідають експериментальним даним, узагальненим у формі (9), розрахунок теплового потоку за наявної різниці температур $\left(t_{w}-t_{s a t}\right)$ та форми врахування фізико-хімічної депресії через середню концентрацію $\Delta_{f c}(\bar{C})$, що зручно при розрахунках випарних апаратів, потрібно виконувати з урахуванням корекції температурного напору величиною $\delta \Delta t$ як

$$
q=\alpha_{m}\left(t_{w}-t_{s a t}-\Delta_{f c}(\bar{C})+\delta \Delta t\right),
$$

де $\delta \Delta t=\left(t_{w}-t_{a v . m}^{\text {exp }}\right)-\left(t_{w}-t_{i}\right)-$ функція, що враховує пригнічення фізикохімічної температурної депресії при кипінні розчинів потоком пари. 
По суті, температура поверхні плівки не відповідає виразу $t_{i}=t_{s a t}+\Delta_{f c}\left(C_{i}\right) \mathrm{i}$ навіть $t_{i}=t_{s a t}+\Delta_{f c}(\bar{C})$ за наявності руху пари над iї поверхнею, що формально рівнозначно поняттю зменшення фізико-хімічної температурної депресії в плівці в міру зростання швидкості пари. Зазначений фактор певною мірою пояснюється охолодженням поверхні плівки рухомою парою, температура якої відповідає тиску насичення - меншої за температуру плівки.

Аналіз експериментальних даних про тепловіддачу до плівок цукрових розчинів концентрацією до $70 \%$ у режимах випаровування 3 міжфазної поверхні та поверхневого кипіння із супутнім паровим потоком дає змогу отримати температурну функцію $\delta \Delta t$ у вигляді залежності:

$$
\delta \Delta t=\left[1-\exp \left(-2,3 \cdot 10^{-2} \sqrt{\mathrm{We}} \sqrt[3]{\mathrm{Pe}}\right)\right] \Delta_{f x},
$$

де $\mathrm{We}=\frac{\rho_{2} u_{2}^{2} d}{\sigma}-$ число Вебера.

Порівняння результатів розрахунків за співвідношенням (6) 3 даними експериментальних досліджень інтенсивності тепловіддачі до вільно стікаючих плівок та при супутньому русі пари зі швидкістю $25 \mathrm{~m} / \mathrm{c}$ води та цукрових розчинів концентрацією до $70 \%$ у режимах випаровування з вільної поверхні та кипіння наведено на рис. 6, 7.

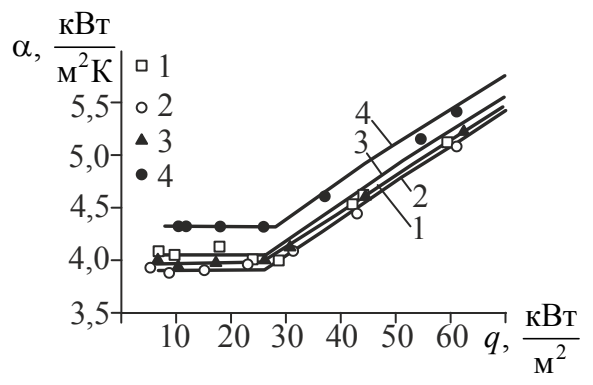

a

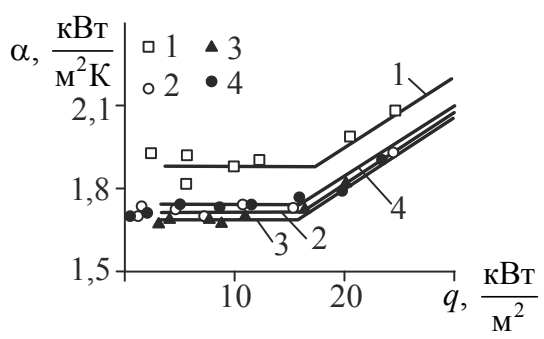

d

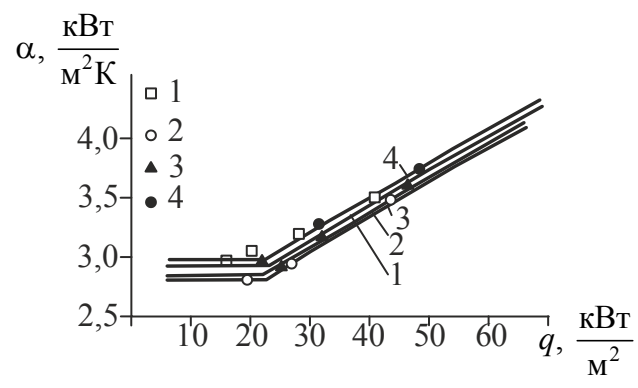

$\mathrm{b}$

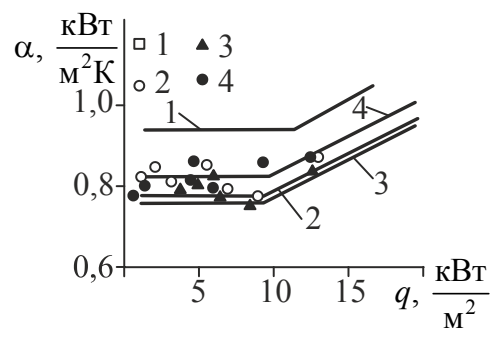

$\mathrm{e}$

Рис. 6. Залежність $\alpha=\boldsymbol{f}(q)$ при вільному стіканні плівок води та цукрових розчинів,

$\left(\boldsymbol{t}=\mathbf{1 0 0}^{\circ} \mathbf{C}, \boldsymbol{R}_{c}=\mathbf{0 , 5} \cdot 10^{-5} \mathbf{M}\right):$ а) вода, $1-\Gamma_{v}=1 \cdot 10^{-4} \mathrm{~m}^{2} / \mathrm{c} ; 2-2 \cdot 10^{-4} ; 3-3 \cdot 10^{-4} ;$

$4-5,5 \cdot 10^{-4} ;$ b) цукровий розчин, $\mathrm{CP}=30 \%, 1-\Gamma_{v}=1 \cdot 10^{-4} \mathrm{~m}^{2} / \mathrm{c} ; 2-1,6 \cdot 10^{-4}$;

$3-2,2 \cdot 10^{-4} ; 4-4,5 \cdot 10^{-4} ;$ d) цукровий розчин, $\mathrm{CP}=50 \%, 1-\Gamma_{v}=0,7 \cdot 10^{-4} \mathrm{M}^{2} / \mathrm{c}$;

$2-1,5 \cdot 10^{-4} ; 3-2,2 \cdot 10^{-4} ; 4-4 \cdot 10^{-4} ;$ е) цукровий розчин, $\mathrm{CP}=70 \%$, $1-\Gamma_{v}=0,5 \cdot 10^{-4} \mathrm{~m}^{2} / \mathrm{c} ; 2-2 \cdot 10^{-4} ; 3-3 \cdot 10^{-4} ; 4-5,5 \cdot 10^{-4}$ 
Лінії відповідають розрахунку за (6) при відповідних щільностях зрошення.

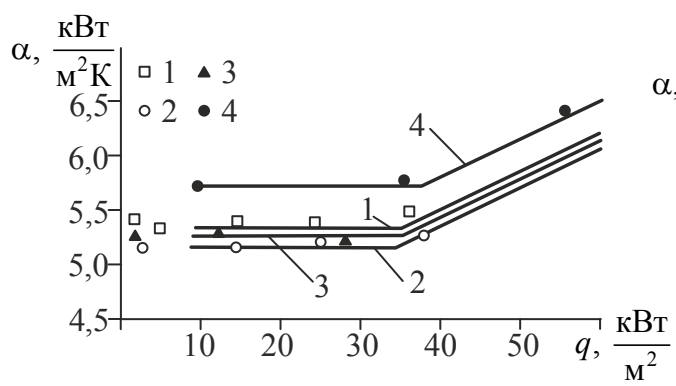

a

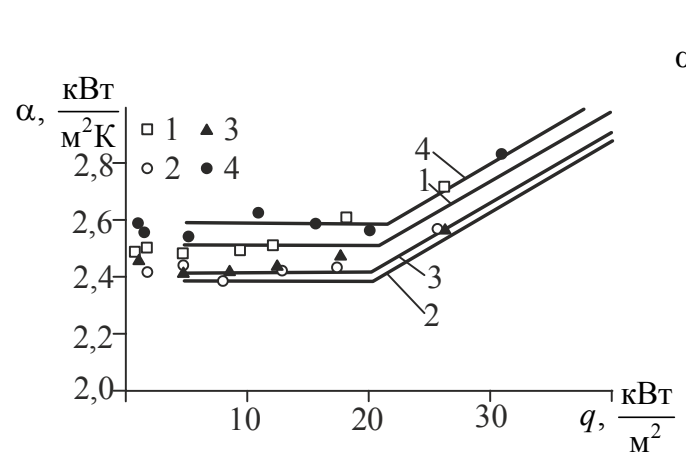

d

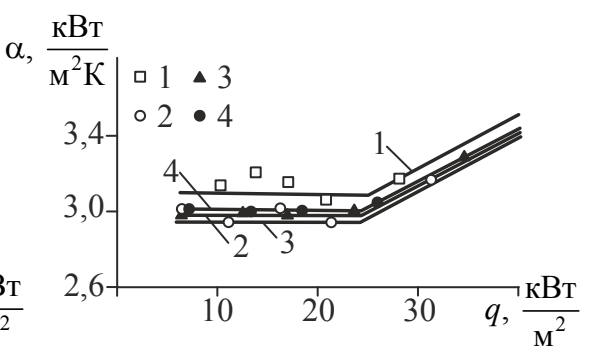

b

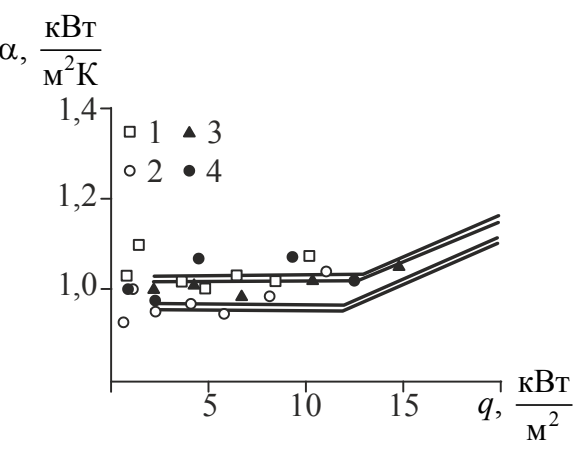

$\mathrm{c}$

Рис. 7. Залежність $\alpha=f(q)$ за швидкості пари $u_{2}=25 \frac{\mathrm{M}}{\mathrm{c}},\left(t=100^{\circ} \mathrm{C}, R_{c}=0,5 \cdot 10^{-5} \mathrm{M}\right)$ :

a) вода, $1-\Gamma_{v}=1 \cdot 10^{-4} \mathrm{~m}^{2} / \mathrm{c} ; 2-2 \cdot 10^{-4} ; 3-3 \cdot 10^{-4} ; 4-5,5 \cdot 10^{-4}$; b) цукровий розчин, $\mathrm{CP}=40 \%, 1-\Gamma_{v}=1 \cdot 10^{-4} \mathrm{~m}^{2} / \mathrm{c} ; 2-1,5 \cdot 10^{-4} ; 3-2 \cdot 10^{-4} ; 4-3,5 \cdot 10^{-4} ;$ d) цукровий розчин, $\mathrm{CP}=50 \%, 1-\Gamma_{v}=1 \cdot 10^{-4} \mathrm{~m}^{2} / \mathrm{c} ; 2-2 \cdot 10^{-4} ; 3-3 \cdot 10^{-4} ; 4-6 \cdot 10^{-4} ;$ е) цукровий розчин, $\mathrm{CP}=70 \%, 1-\Gamma_{v}=1 \cdot 10^{-4} \mathrm{~m}^{2} / \mathrm{c} ; 2-2 \cdot 10^{-4} ; 3-3 \cdot 10^{-4} ; 4-5,5 \cdot 10^{-4}$

Лінії відповідають розрахунку за (6) при відповідних щільностях зрошення.

Як видно з наведених графіків, перехід до режиму кипіння зі зростанням швидкості пари зміщується в область більших теплових потоків і задовільно ідентифікується параметром $(3,4)$.

У разі застосування шорстких труб $\left(R_{c} \geq 0,5 \cdot 10^{-5} \mathrm{M}\right)$, наприклад, після ощищення поверхні жорсткими металевими щіками або нанесення штучної шорсткості, відповідно до (3), (4) перехід до режиму кипіння відбудеться при менших теплових потоках з відповідною інтенсифікацією процесу теплообміну.

Крім вище визначених чинників, на інтенсивність тепловіддачі має вплив і геометрія каналу, оскільки як довжина, так і діаметр труб впливають на розвиток хвильової структури. Так, у дев'ятиметрових кип'ятильних трубах [4] зі зміною відстані від розподільного пристрою до 3-4 м має місце i незначне зростання інтенсивності тепловіддачі при тих самих витратних i режимних параметрах потоків, що і в коротких трубах. Крім того, за даними 
досліджень кінематики хвильового руху [8; 9] збільшення діаметра труби також призводить до зростання амплітуди та довжини великих хвиль, що інтенсифікує процеси перемішування в плівці.

Але виділити вплив окремих факторів на тепловіддачу з даних, які отримані на установках, що моделюють випарний апарат, неможливо, оскільки по довжині труби одночасно наростає і швидкість пари, і концентрація пропорційно тепловому потоку. Так, змоделювати процес теплообміну при вільному стіканні можна лише на верхніх ділянках труби, де швидкість пари незначна, але нерозвинута хвильова структура. Дані, що відповідають області з розвинутою хвильовою структурою, розташовані в середній і нижній частинах труб, де швидкість пари має відчутний вплив на тепловіддачу. Тому і порівняння експериментальних даних про тепловіддачу в модельних трубах випарних апаратів 3 даними, отриманими на установках 3 незалежним формуванням витрат фаз, коректне лише за наявності певної швидкості пари.

На рис. 8 нанесені масиви даних про теплообмін у плівках в каналах різної конфігурації, які порівняно з результатами розрахунку за апроксимаційним рівнянням (6) з поправкою (12).

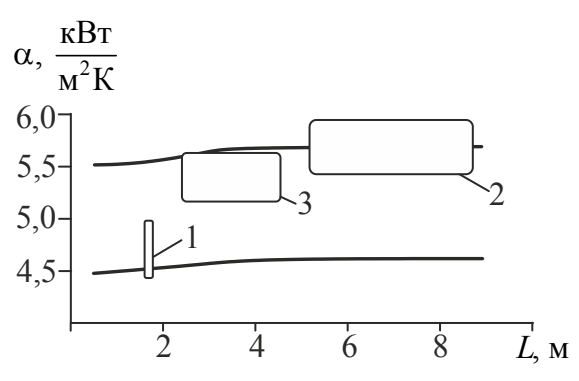

a

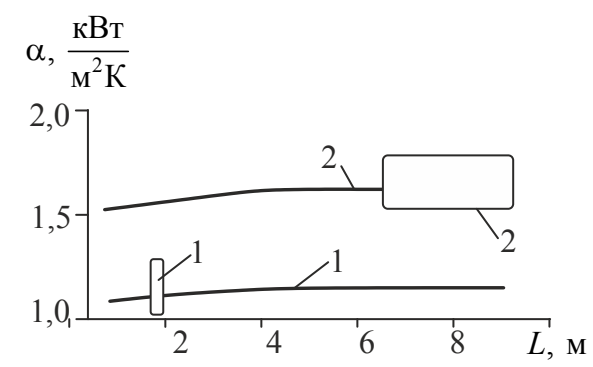

$\mathrm{b}$

Рис. 8. Залежність $\alpha=f(L):$ a) вода, $\left.\boldsymbol{u}_{2}=15 \frac{\mathrm{M}}{\mathrm{c}} ; \mathrm{b}\right)$ цукровий розчин, $\mathrm{CP}=70 \%$, $\boldsymbol{u}_{2}=\mathbf{3 0} \frac{\mathbf{M}}{\mathbf{c}}$, де 1 - область даних авторів, $d=20$ мм, $L=1,8$ м; 2 - область даних [4], $d=$ 30 мм, $L=9$ м; 3 - область даних [10], $d=32$ мм, $L=4,9$ м

Лінії відповідають розрахунку за (6), $1-d=20$ мм, $2-30$ мм.

Оцінити вплив фактора довжини та діаметра труб на тепловіддачу можна введенням співмножника $K_{L}$ до (6), отриманого порівнянням результатів досліджень інтенсивності тепловіддачі до плівок у трубах різної геометрії:

$$
K_{L}=\left\{1+0,06\left(\frac{v}{v_{o}+v}\right)\left[1-\exp \left(-0,05 L^{3}\right)\right]\right\}\left(\frac{d}{d_{o}}\right)^{0,35-0,06\left(\frac{d}{d_{o}}\right)},
$$

де $d_{o}=0,02 \mathrm{M}, v_{o}=0,3 \cdot 10^{-6} \frac{\mathrm{m}^{2}}{\mathrm{c}} ; L-$ довжина труби в м ( від $\left.1 \mathrm{м}\right)$.

Оскільки коефіцієнт тепловіддачі є величиною маніпулятивною, особливо при узагальненні даних при кипінні розчинів, залежно від того, до якої 
різниці температур віднесений тепловий потік, адекватність моделі підтверджується відповідністю відтвореного розрахункового розподілу теплового потоку по висоті труби реальній зміні за певної загальної різниці температур.

Графічна інтерпретація результатів моделювання теплового потоку по довжині труби довжиною 9 м за співвідношеннями (5), (6), (10), (11), (12) та ïx порівняння з експериментальними даними [4] наведено на рис. 9a, б, с, а для киплячих під розрідженням 0,65 бар і 0,87 бар яблучних сиропів у трубі діаметром 32 мм, довжиною 3,9 м - на рис. 9д, е.
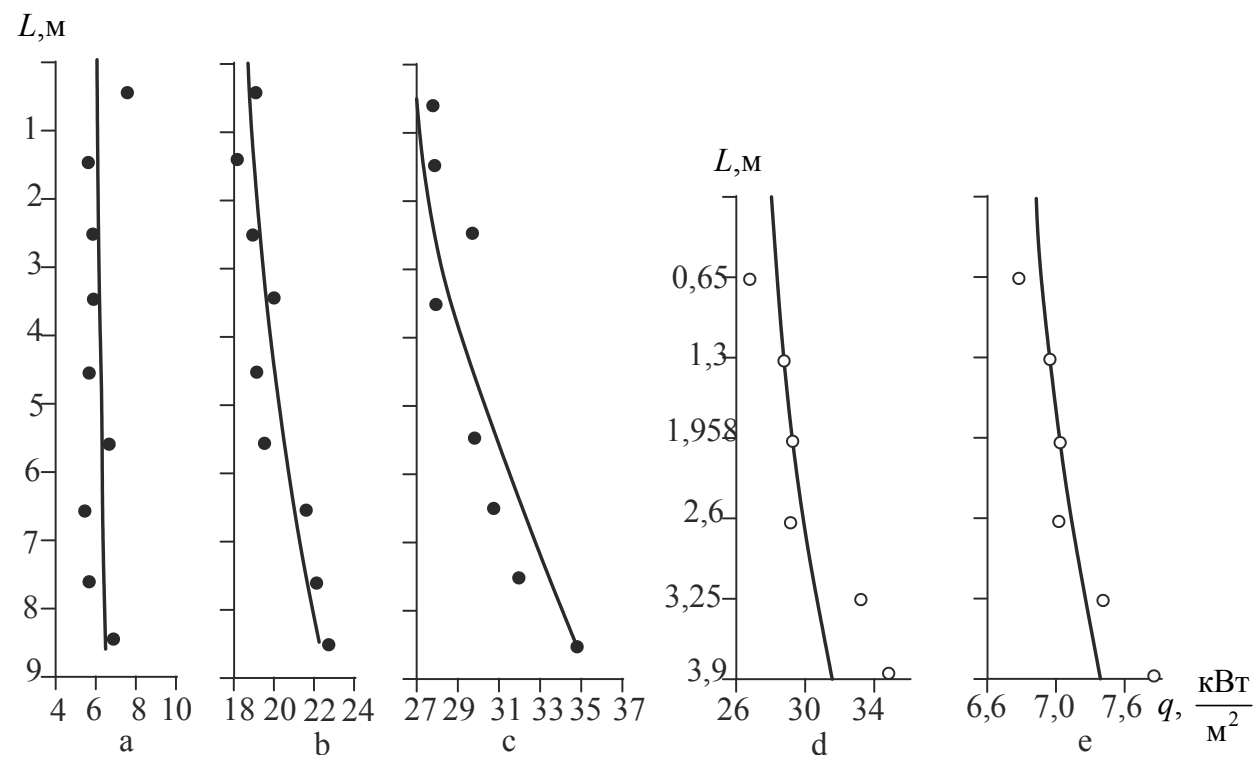

Рис. 9. Розподіл теплового потоку по висоті кип'ятильної труби, де лінії - розахунок за (6 ); а, б, с- вода $t=100^{\circ} \mathrm{C} ; L=9 \mathrm{M}, d=30 \mathrm{Mм}, \Gamma_{v}=0,310^{-3} \mathrm{~m}^{2} / \mathrm{c}$, точки - експериментальні дані [4]; $\mathrm{a}-\Delta t=2,2^{\circ} \mathrm{C}, t_{w}-t_{\text {sat }}=1,2 ; \mathrm{b}-7,5, t_{w}-t_{\text {sat }}=3,7 ; \mathrm{c}-11, t_{w}-t_{\text {sat }}=5,1$; $\mathrm{d}$, е - яблучний сироп, $L=3,9 \mathrm{M}, d=32$ мм: д) $\mathrm{CP}=16,3 \%, P=0,35$ бар, $t_{o}-t_{\text {sat }}=15,6^{\circ} \mathrm{C}$;

е) $\mathrm{CP}=60,4 \%, P=0,13$ бар, $t_{o}-t_{\text {sat }}=9,5^{\circ} \mathrm{C}, t_{o}-$ температура нагрівної пари

У рівнянні (6) не відображені дані, що відносяться до коротких ділянок, де відбувається формування температурного та гідродинамічного поля 3 нерозвинутою хвильовою структурою, тому застосування (6) обмежено довжиною від 1 м і більше.

\section{Висновки}

1. Параметром, що ідентифікує початок кипіння в плівці, доцільно обирати величину критичного перегріву стінки (3), (4), який адекватно реагує як на зміну тиску або розрідження, так і на стан теплообмінної поверхні.

2. Температура поверхні плівки розчинів у режимі випаровування з міжфазної поверхні не відповідає виразу $t_{i}=t_{\text {sat }}+\Delta_{f c}\left(C_{i}\right)$ при наявності руху пари над ії поверхнею, а $€$ меншою, що формально рівнозначно поняттю зменшення фізико-хімічної температурної депресії в плівці у міру зростання швидкості пари. 
3. Узагальнююче інженерне рівняння (6) для розрахунку коефіцієнта тепловіддачі до стікаючих по вертикальній поверхні насичених плівок води та цукрових розчинів концентрацією до $70 \%$ дійсне в режимах як випаровування з вільної поверхні, так і кипіння, включаючи область розрідження до 0,85 бар і теплових потоків до 60 кВт/м², в діапазоні об'ємної щільності зрошення $0,05 \ldots 0,6 \cdot 10^{3} \mathrm{~m}^{2} / \mathrm{c}$, швидкості пари до $40 \mathrm{~m} / \mathrm{c}$ і коректне для труб діаметром від 20 до 32 мм (досліджений діапазон) та довжин від 1 м.

\section{Лiтература}

1. Petrenko $V$. Heat transfer modeling in down-flowing laminar films with the developed wavy structure with co-current steam flow[text] / V.Petrenko,Y. Zasyadko // Food and Environment safety (FES). - 2016. - Vol 15, Issue 3. - P. 203-215.

2. Petrenko $V$. Heat transfer in down flowing turbulent evaporating liquid film with developed wavy structure and co-current steam flow [text] / V. Petrenko,Y. Zasyadko // Food and Environment safety (FES). — 2016. — Vol. 15, Issue 4. — P. 284-298.

3. Ганчев Б.Г. Охлаждение элементов ядерных реакторов стекающими пленками [Текст] / Б.Г. Ганчев. — Москва : Энергоатомиздат, 1987. — 192 с.

4. Ардашев B.A. Исследование теплообмена при выпаривании гравитационно-стекающей пленки жидкости в вертикальных трубах [Текст] : дис. ... канд. техн. наук / В.А. Ардашев. - Киев, 1983. - 188 с.

5. Chun K.R. Heat Transfer in Evaporating Liquid Films. [text] / K.R.Chun, R.A. Seban// Heat Transfer.-1971. - No. 4.- P. 71-77.

6. Серза M. Пузырьковое кипение в стекающей водяной ламинарной пленке на участке тепловой стабилизации и при полностью развитом течении [Текст] / М. Серза, В. Сернас // Труды ASME - Теплопередача сер. - 1988. — № 4. - C. 165-174.

7. Fujita T. Heat Transfer to Falling Liquids Films and Film Breakdown — Part II. Saturated Liquid Films With Nucleate Boiling [text] / T.Fujita, T.Ueda // Int.J.Heat Mass Transfer. 1978. - Vol. 21, No. 2. - P. 109-118.

8. Кулов Н.Н. Гидродинамика и массообмен в нисходящих двохфазных пленочно-дисперсных потоках. [Текст]: дис. ... докт. техн. наук / Н.Н. Кулов. — Москва, 1984. - 409 с.

9. Chu K.J. Statistical characteristics of thin, wavy films. Pt 111, Structure of the large waves and their resistance to gas flow [text] / K.J. Chu, A.E. Dukler // AIChE.J. — 1975. Vol. 21, No. 3. - P. 583-593.

10. Левераш В.И. Экспериментальное исследование теплоотдачи к жидкости в выпарных аппаратах с падающей пленкой применительно к условиям работы дистилляционных опреснительных установок. [Текст]: дис. ... канд. техн. наук / В.И. Левераш. - МЭИ, 1964. $-24 \mathrm{c}$. 